\title{
Landscape Ecology in a Watershed of the Ocoy River, Western Parana State, Brazil
}

\author{
Diogo Seganfredo $^{1}$ (D), Bruna Cunha ${ }^{1}$ (D), Vanderlei Leopold Magalhães ${ }^{2}$ (D), \\ Roque Cielo-Filho ${ }^{3}$ (D), Carla Daniela Câmara² \\ ${ }^{1}$ Programa de Pós-graduação em Tecnologias Ambientais, Universidade Tecnologica Federal do Paraná - UTFPR, \\ Medianeira/PR, Brasil \\ ${ }^{2}$ Departamento de Ciências Biológicas e Ambientais, Universidade Tecnologica Federal do Paraná - UTFPR, \\ Medianeira/PR, Brasil \\ ${ }^{3}$ Floresta Estadual de Avaré, Instituto Florestal - IF, Avaré/SP, Brasil
}

\begin{abstract}
This study evaluated the landscape structure of a watershed located in a region considered strategic for the implementation of the Paraná River Biodiversity Corridor. Based on land-use/land-cover mapping, four different scenarios were generated: 1) real situation, 2) considering the edge effect, 3) without Permanent Preservation Areas (APPs), and 4) with restoration of the riparian APPs. Different landscape metrics were calculated for each scenario. In scenario 2 , only $28 \%$ of the total natural vegetation cover remained as core areas. In scenario 3 , there was a considerable increase in forest fragmentation. In scenario 4, an expressive increase in landscape connectivity was promoted. In conclusion, a relatively small increase in natural vegetation cover can promote considerable increase in landscape connectivity and restoration of the riparian APPs in watersheds of the region should be considered as a priority action for the implementation of the Paraná River Biodiversity Corridor.
\end{abstract}

Keywords: connectivity, landscape metrics, biodiversity corridors. 


\section{INTRODUCTION}

Western Parana presents one of the highest levels of fragmentation of natural vegetation in that state (Tossulino et al., 2007). This region is part of the Upper Parana Atlantic Forest Ecoregion - one of the 15 ecoregions identified in the Atlantic Forest Biome (Di Bitetti et al., 2003), and comprises two important protected areas: the Iguaçu National Park and the Parana River Permanent Preservation Area, located along the banks of the Itaipu Hydroelectric Power Plant reservoir.

Because these two protected areas are relatively distant and isolated from each other, the World Wildlife Fund (WWF-Brazil) has stated in its Biodiversity Conservation Landscape map that the region between them should be considered as an area that requires biodiversity corridor (Di Bitetti et al., 2003). These corridors are seen as local proposals aimed at consolidating, on a broader scale, the Parana River Biodiversity Corridor. This corridor is crucial for avoiding genetic isolation among the biota remnants of the semideciduous seasonal forests located in the states of Sao Paulo and Mato Grosso do Sul in southern Brazil, as well as in northwestern Argentina and eastern Paraguay (Di Bitetti et al., 2003).

One of the alternatives to diminish the isolation between these two protected areas is the recovery of riparian forests in the watersheds of the region (Muchailh et al., 2010), considering that this vegetation that occupies Permanent Preservation Areas (APPs) is important for fauna movement and plant dispersal, greatly contributing to biodiversity conservation in fragmented landscapes (Lima \& Zákia, 2000; Lees \& Peres, 2008; Jesus et al., 2012).

Conservation and recovery of riparian forests, forming ecological corridors, result in significant improvements in landscape ecology not only because of the increase in forest cover, but also of the decrease in the number of small fragments, enabling the formation of larger and less isolated polygons of natural vegetation (Muchailh et al., 2010).

In addition to isolation, the remaining fragments suffer negative influences on their edges - the so-called edge effect. In fragmented landscapes, the edges of natural vegetation fragments are the areas most impacted by anthropic activities. They also undergo greater changes in microclimatic conditions such as increased light and temperature, decreased soil moisture, greater interference from winds, among others, with negative consequences for biota (Harper et al., 2005; Tabarelli et al., 2008; Metzger, 2009).

This study aims to evaluate aspects of landscape structure associated with biodiversity conservation in a watershed located in western Parana state, a region of strategic importance for the implementation of the Parana River Biodiversity Corridor. Its specific objective is to describe land use and land cover in this watershed, considering the edge effect and the importance of riparian APPs for landscape ecology.

\section{MATERIAL AND METHODS}

The Ocoy River Basin lies between the Iguaçu National Park and the reservoir of the Itaipu Hydroelectric Power Plant, which are located in the Upper Parana Atlantic Forest Ecoregion, Parana state, Brazil. This is the largest of the 15 ecoregions identified in the Atlantic Forest Biome, and its predominant vegetation is the semideciduous seasonal forest (Di Bitetti et al., 2003).

The present study was conducted in a watershed located in the Ocoy River Basin. This particular watershed was selected based on the spatial distribution of its hydrographic network and on its potential for connecting the Iguaçu National Park and the Itaipu Reservoir Permanent Preservation Area. The watershed under study is 1,888 ha large. Its southeast border is $12 \mathrm{~km}$ far from the Iguaçu National Park and its northwest border is at a distance of $14 \mathrm{~km}$ from the Itaipu Reservoir (Figure 1).

\subsection{Land use and land cover mapping}

The Georeferenced Information Processing System (SPRING), version 5.2.6, was used for the creation of thematic maps. The database was structured in a project with UTM cartographic projection, zone 21, SIRGAS 2000 datum, and a surrounding rectangle with the following coordinates: west longitude between $53^{\circ} 59^{\prime}$ and $54^{\circ} 05^{\prime}$ and south latitude between $24^{\circ} 14^{\prime}$ and $25^{\circ} 20^{\prime}$. Georeferenced images from the French satellite Pleiades were imported into this database from the green (band 2), red (band 3), and near infrared (NIR, band 4) bands, with spatial resolution of $2 \mathrm{~m}$ and coverage as of March 2014. 


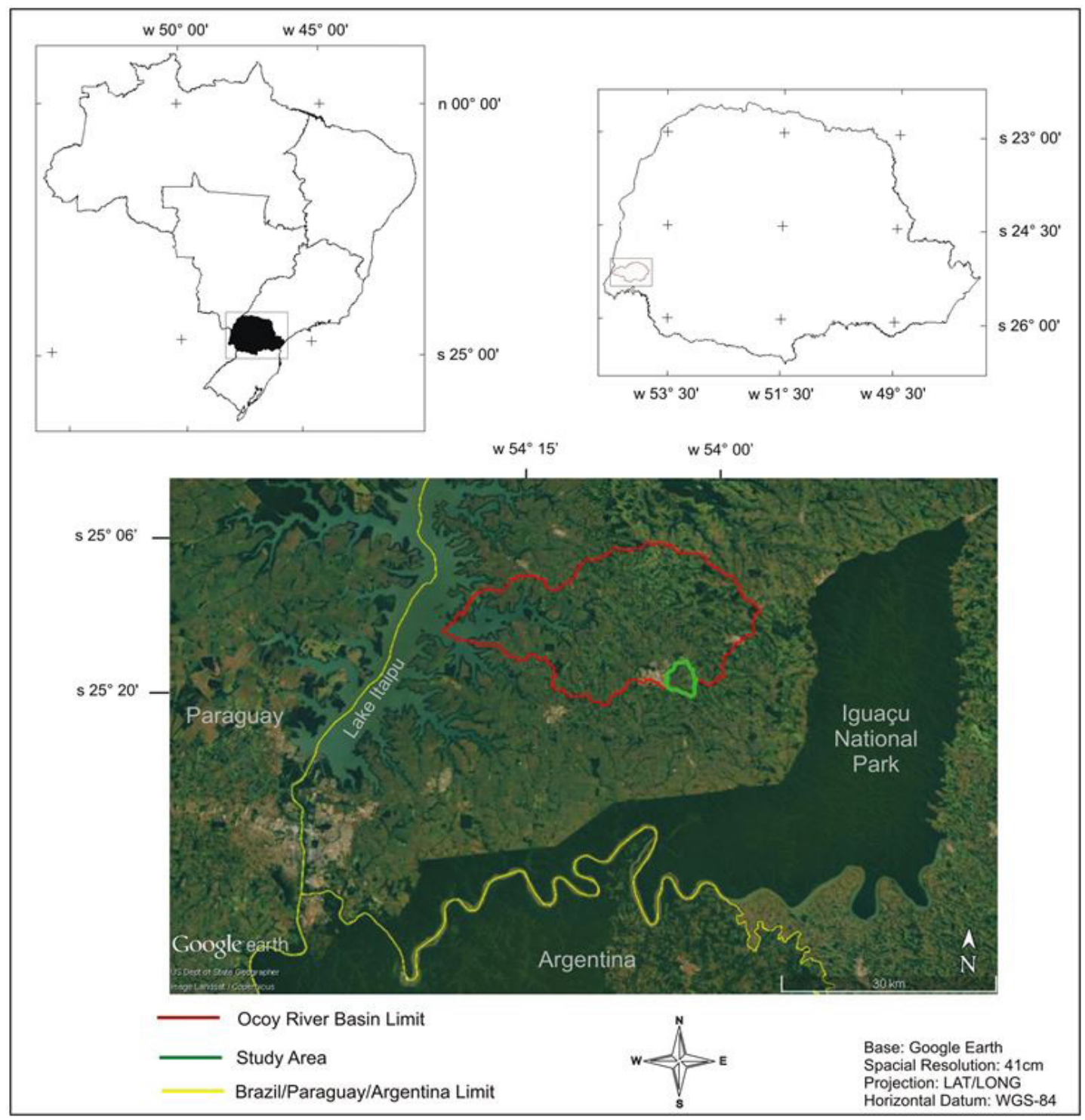

Figure 1. Location of the study area.

Using SPRING enhancement mechanisms, a synthetic "false color" image was generated, associating these different electromagnetic spectrum bands with the following colored compositions: 2 (blue), 3 (red), and 4 (green). Association of the green color with the NIR band enables easier recognition of vegetation and exposed soil.

Classification of land use and land cover was performed in screen scanning. The following classes were established for this classification: agriculture, pasture, natural vegetation, reforestation, residential and circulation areas, roads, and lakes/reservoirs.
In the study area, the original soil cover is exclusively forested, thus the natural vegetation class corresponds to remaining forest fragments.

\subsection{Delimitation of permanent preservation areas}

Federal Law no. 12.651, dated May 25, 2012, and known as the New Brazilian Forest Code, was employed for determination of the Permanent Preservation Areas (APPs). In order to establish the APP range, a width of at least 15 meters was considered around watercourses 
and springs, as determined in the article 61-A of the aforementioned Law (regarding rural properties with an area larger than two and up to four fiscal modules). The use of the property size parameter was based on the classification of the rural properties located in the study region (Brasil, 1980; Paraná, 2003).

\subsection{Delimitation of fragment edges}

The core area, disregarding the edge areas, was used to indicate the nuclear area of the fragment. For this study, the width of the edge area was $50 \mathrm{~m}$. This criterion was taken from the evaluation performed by Fontoura et al. (2006) regarding the extent of penetration of the edge effect in a forest fragment according to the changes of the plant community in relation to species richness and abundance. Thus, for delimitation of the edge areas, a $50 \mathrm{~m}$ extension from the edge towards the interior of the fragments was considered in the studied landscape.

\subsection{Landscape ecology metrics}

Landscape ecology metrics were calculated based on the land use and land cover map. To diagnose the landscape as a whole, land cover classes were determined by calculating their percentage. At the level of forest fragments, seven metrics of landscape ecology were calculated for each scenario (see ahead): natural vegetation total cover, expressed in hectares and percentage; number of fragments; average size and average shape index of fragments; average distance to the nearest neighbor; and average connectivity between remnants, measured by the proximity index (PROX) metric (see ahead).

Determination of the shape factor, the so-called "circularity index", was based on the methodology proposed by Miller (1953) (apud Christofoletti, 1974), conventionally used for determining the shape of river basins, and adapted for forest fragments polygons. As the index value decreases and distances from 1 , the greater the tendency of the fragment to display a more elongated shape, and thus be more exposed to edge effect (Greggio et al., 2009; Silvério et al., 2015).

PROX was the metric used to calculate connectivity between the fragments of the study area. This metric is based on the ratio between the total sum of the areas of fragments of the same class as the target fragment and the sum of the respective Euclidean edge-to-edge distances, considering only the fragments within the search radius (McGarigal \& Marks, 1995). PROX value may be zero when there is no fragment of the same class of the target fragment within the stipulated radius, and it increases as the areas of fragments of the same class increase and the distances from the target fragment to their neighbors decrease.

For determination of PROX, a search radius of 500 meters was established based on Milet-Pinheiro \& Schlindwein (2005). According to their findings, males of some Euglossini species are be able to link isolated fragments by flying distances of $500 \mathrm{~m}$ between them in a fragmented landscape. This is one of the alternatives for determination of PROX values in the assessment of landscape connectivity. The use of Euglossini bees to determine the search radius considers the relevant role played by these bees in the pollination of several plant species in tropical and subtropical forests (Aguiar \& Gaglianone, 2012).

Unfortunately, no results have been found in the literature allowing for uniformization of abiotic variables and taxonomic groups used to define the range distance of edge effect and of search radius defined for calculation of PROX metric. In this context, we aimed to provide a possible assessment of the landscape structure.

\subsection{Evaluated scenarios}

Landscape metrics were calculated for the natural vegetation class in four different scenarios: 1) real situation; 2) considering the edge effect to assess the impact of this effect at landscape level; 3) disregarding the riparian APPs to assess the effect of APP removal on landscape ecology; and 4) considering restoration of the riparian APPs devoid of natural vegetation to ascertain the benefits that would be achieved with the recovery of these areas.

\section{RESULTS AND DISCUSSION}

In the distribution of land use and land cover, the following classes were identified: annual crops (51.5\%); natural vegetation (24.5\%); pastures (18.6\%); houses, buildings, and circulation areas (3.2\%); reforestation $(1.9 \%)$; roads $(0.2 \%)$; lakes and reservoirs $(0.2 \%)$ (Figure 2). This distribution was similar to that found in the municipality of Céu Azul, located near the 


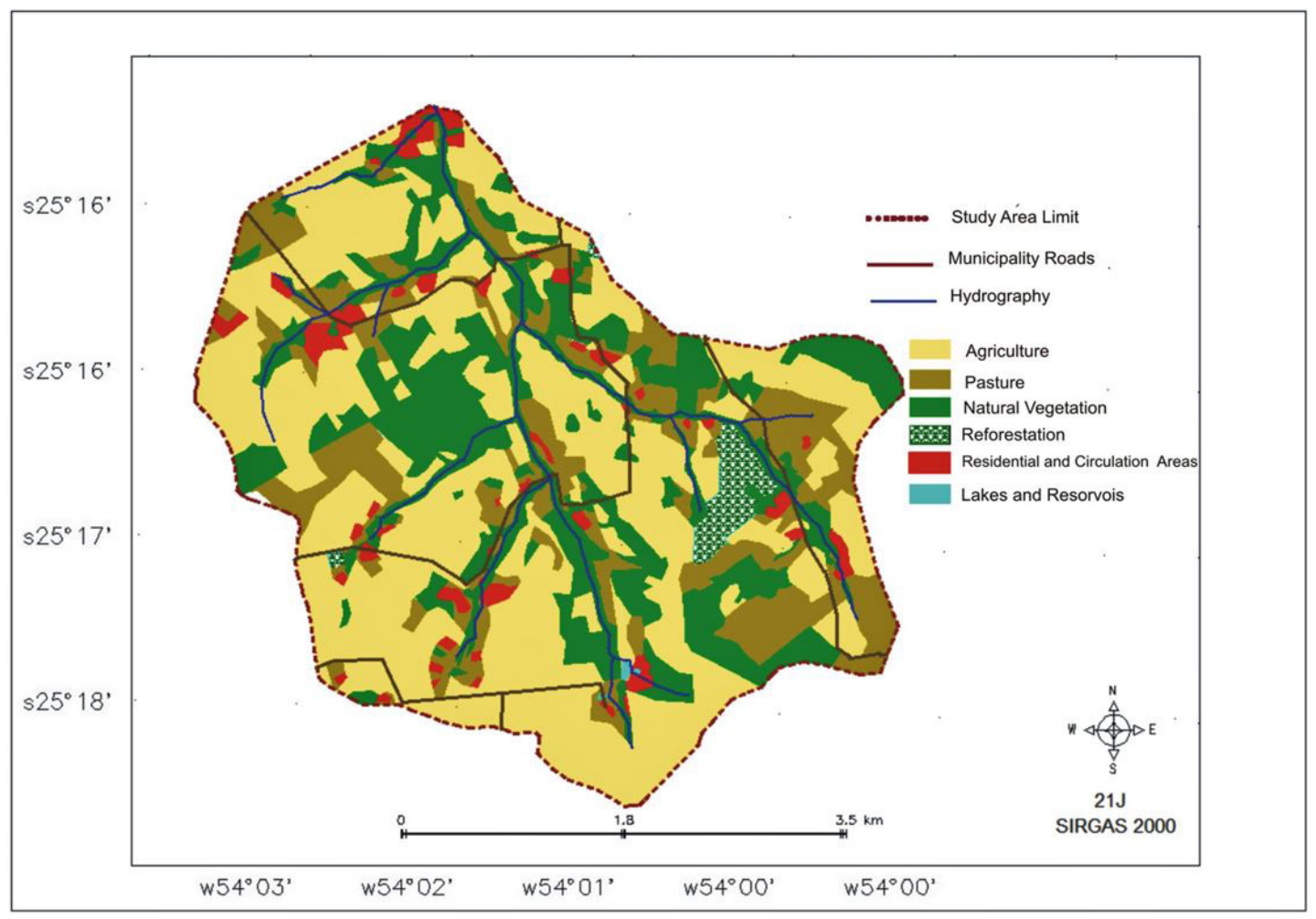

Figure 2. Land use/land cover map.

study area, where predominance of agricultural use was observed, followed by natural vegetation and pastures (Muchailh et al., 2010). With respect to the native vegetation cover found in the study area (24.5\%), although larger than that found by Muchailh et al. (2010), it is still much smaller than that recommended as ideal by Metzger (2009): maintenance of $60-70 \%$ of the original habitat for a landscape to present a suitable structure for conservation purposes.

Regarding the riparian APPs, a deficit of 14.7 ha was observed, even with the application of the less stringent parameters of the New Forest Code (Brasil, 2012), which reduced by $50 \%$ the width of APP buffer strips along watercourses in rural areas. The riparian APPs totaled 59.9 ha in the watershed as a whole, so the percentage of forest cover deficit in those areas was 25\%. No non-riparian APPs were found.

Assessment of the watershed landscape ecology verified that the real situation, scenario 1 , revealed that $24.5 \%$ of the study area presents natural vegetation (Table 1; Figure 3). The relatively large number of fragments, 46 , contributes to a relatively low average size, $11.6 \mathrm{ha}$, when compared with those of other studies. Calegari et al. (2010), in an analysis conducted also on fragments of semideciduous seasonal forest, located in the municipality of Carandaí, Minas Gerais state, found a more expressive result, 30.6 ha, for the average size of fragments.

Average fragment size presented a worse result when the edge effect was applied (scenario 2). In this scenario, the average size of the fragments was $4.6 \mathrm{ha}$. This decrease was caused by a $72 \%$ reduction in the total area of natural vegetation, from $24.5 \%$ of total area index in the real situation to only $6.8 \%$. In scenario 2 , a drastic reduction in the number of fragments was also observed, considering that from the 46 remnants in the real situation, only 28 presented areas free of the influence of edge effect.

Despite their importance, small fragments may suffer greater edge interference. Edge effect is one of the main agents causing biodiversity decline (Harper et al., 2005; Tabarelli et al., 2008; Gomide \& Lingnau, 2009; Metzger, 2009). The observed $72 \%$ reduction in native forest cover caused by the edge effect follows a trend 
Table 1. Comparison of metrics in different scenarios of natural vegetation. Scenario 1: real situation; Scenario 2: applying the edge effect; Scenario 3: disregarding the riparian APPs; Scenario 4: considering restoration of the riparian APPs devoid of natural vegetation.

\begin{tabular}{|c|c|c|c|c|}
\hline Metrics & Scenario 1 & Scenario 2 & Scenario 3 & Scenario 4 \\
\hline Total class area (ha) & 463.5 & 129.7 & 418.3 & 478.2 \\
\hline Total area index $(\%)$ & 24.5 & 6.8 & 22.1 & 25.3 \\
\hline Number of fragments & 46 & 28 & 95 & 25 \\
\hline Average size of the fragments (ha) & 11.6 & 4.6 & 4.4 & 19.1 \\
\hline Average shape index & 0.43 & 0.42 & 0.21 & 0.68 \\
\hline Average distance from nearest neighbor ( $\mathrm{m})$ & 82.1 & 216.8 & 52.4 & 94.8 \\
\hline Average PROX & 15.1 & 8.2 & 28.6 & 338.8 \\
\hline
\end{tabular}

APPs - Permanent Preservation Areas; PROX - Proximity index.

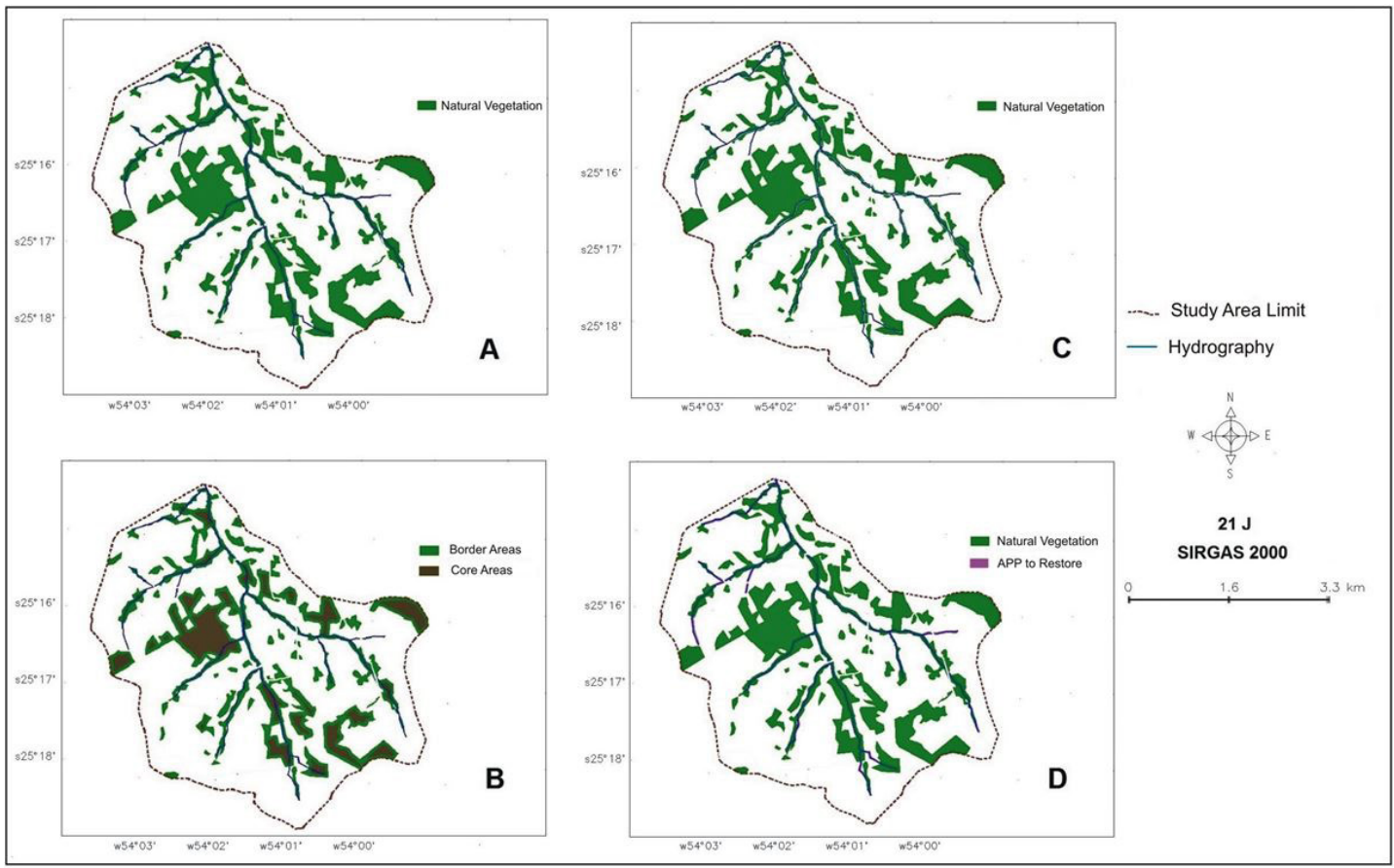

Figure 3. Different landscape scenarios: (A) scenario 1 - real situation; (B) scenario 2 - considering the edge effect; (C) scenario 3 - disregarding the presence of the riparian APPs; (D) scenario 4 - considering restoration of the riparian APPs devoid of natural vegetation. APPs - Permanent Preservation Areas.

observed in other studies. Considering an average penetration distance of $30 \mathrm{~m}$ for edge effect, Vidolin et al. (2011) reported a reduction of $51 \%$ of the effective area of natural forest fragments.

The only scenario that resulted in increased average size of fragments was scenario 4, a hypothetical situation in which all riparian APPs would have natural vegetation. This scenario showed an increase of only $3.2 \%$ in the total of the natural vegetation class, but with a $65 \%$ increase in the average size of the fragments, which raised to 19.1 ha. Even so, they still would have an average size lower than 50 ha, a size that Ribeiro et al. (2009) pointed as small and insufficient for the maintenance of biodiversity. On the other hand, Calegari et al. (2010) emphasized the importance of these fragments for connectivity, advocating that, in spite of being small, they fulfill relevant functions in the conservation of landscape biodiversity.

In scenario 1, the fragments analyzed presented an average shape index of 0.43 . Larger indices were found by Silvério et al. (2015) in fragmented landscapes of the Atlantic Forest in the municipality of Três Rios, 
Rio de Janeiro state, where the average shape indices in the four landscapes studied ranged from 0.55 to 0.59 . Nevertheless, these authors alerted to the risk of loss of biodiversity in the region due to the elongated or irregular shapes of the fragments. In this sense, the importance of riparian APPs for this study area is highlighted, considering that in scenario 3 , assessment of the landscape structure without the existence of riparian vegetation showed a much lower shape index average value, 0.21 , indicating fragments with even more elongated shapes and more exposed to the edge effect than in the real situation.

In contrast, the fragments analyzed with the presence of all riparian APPs (scenario 4) presented an average shape index of 0.68 . Although the elongated shape inherent to riparian APPs suggests a lower circularity and, consequently, a lower average shape index, an opposing trend was observed for this metric in scenario 4 . This apparently contradictory result can be explained by the fact that the recovery of riparian APPs projected in scenario 4 resulted in connection between fragments and consequent decrease in the number of fragments in the landscape. Thus, the denominator decreases in the calculation of the shape index average value overcompensated the decrease in circularity, resulting in a higher average shape index.

In the isolation analysis, the average distance to the nearest neighbor in all scenarios did not exceed 500 meters. Theoretically, it would allow some species of Euglossini bees to move from border to border in the fragments in the four scenarios. In Scenario 3, the fragments are closer $(52.4 \mathrm{~m})$, as there is an increase in the influence of the smaller distances in the calculation of the average, in view of the creation of fragments in the landscape separated by a distance of only $30 \mathrm{~m}$ - the width of the riparian APP considered in this study. In scenario 2 , as expected due to the effect of edge removal, a significant increase in the average distance between fragments $(216.8 \mathrm{~m})$ was observed. In the real situation, the average distance was $82.1 \mathrm{~m}$. In the landscapes studied by Silverio et al. (2015), the average distances between fragments varied between 103 and $743 \mathrm{~m}$, whereas in the study by Muchailh et al. (2010), the value found was $79 \mathrm{~m}$.

Persistence of many species of animals in fragmented landscapes depends on their ability to move between habitat fragments, which vary according to the species.
Some species of birds, for example, are very demanding as to the limit of the distance of displacement between habitat fragments. Awade \& Metzger (2008) found limiting distances of 60 and $80 \mathrm{~m}$ for two Atlantic Forest bird species. Considering the average distance to the nearest fragment in our study area, such species would encounter difficulties in passing from one fragment to the other, and would present low probability of persistence in the landscape.

Evaluation of connectivity by means of the PROX metric showed low values, mainly when compared with those of other studies. Scenario 4 that presented the highest PROX average, with a value 22 times higher than that of scenario 1 . Therefore, in scenario 4 , restoration of the riparian APPs, although not representing a significant change in the total class area, impacted connectivity significantly according to the PROX metric data. Mello et al. (2014) found a greater increase in the natural vegetation class with the restoration of APPs in a study conducted in the municipality of Sorocaba, Sao Paulo state, increasing from $16.6 \%$ to $28 \%$, accompanied by significant increase in PROX values and landscape connectivity. The 22 -fold increase in the PROX mean value in scenario 4 indicates the possibility of significant enhancement in the gene flow of plant species in the studied landscape, considering the important role played by Euglossini bees in the pollination of plant species in tropical and subtropical forests (Aguiar \& Gaglianone, 2012).

In the present study, analysis of the environment with restoration of the riparian APPs devoid of natural vegetation showed an increase in the area and a reduction in the number of natural vegetation fragments, evidencing that restoration of the riparian APPs rendered the landscape less fragmented and considerably more connected. Calegari et al. (2010) warned about the importance of forest restoration, mainly in areas of permanent preservation and Mello et al. (2014) stated that recovery of APPs significantly improves landscape connectivity.

Considering that riparian vegetation follows the spatial configuration of rivers forming long and continuous buffer strips in the landscape along their course, it tends to form more irregularly shaped fragments (Vidolin et al., 2011) with less circularity than others more rounded fragments of same area. Thus, it is worth highlighting that the decrease in the legal 
requirement for the width of riparian APPs introduced by the New Forest Code (Brasil, 2012) lessened the potential of these areas of natural vegetation to promote reduction of the susceptibility of fragments to edge effect. However, even with a reduced width, the results indicate the extreme importance of riparian APPs for the maintenance of connectivity in landscapes with fragmented natural vegetation cover.

The connection between the Iguaçu National Park and the Permanent Preservation Area of the Itaipu Hydroelectric Power Plant Reservoir on the Parana River can significantly contribute to the conservation of the Atlantic Forest biodiversity (Di Bitetti et al., 2003). This permanent preservation area is approximately $2,900 \mathrm{~km}$ long and $217 \mathrm{~m}$ wide on average, and comprises reforestations and remnants of native forests along almost all the banks of the reservoir (Itaipu Binacional, 2015a). An example of an attempted connection between the two protected areas is the Santa Maria Corridor, which consists of remnants of native forest and a $60 \mathrm{~m}$ wide reforestation belt in the Rio Bonito River basin in the municipality of Santa Terezinha de Itaipu, Parana state (Itaipu Binacional, 2015b). However, this initiative is considered insufficient for an effective connection, and the need for a broader corridor is suggested (Di Bitetti et al., 2003). The present study evidenced that the simple restoration of native riparian forests in the watersheds of the region can significantly increase the connectivity of the landscape and the connection between the Iguaçu National Park and the Permanent Preservation Area of the Itaipu Hydroelectric Power Plant Reservoir, consequently contributing to the implementation of the Parana River Biodiversity Corridor.

\section{CONCLUSIONS}

This study verified that, in a scenario in which native vegetation cover is restricted to the core areas of forest fragments, there is drastic reduction in the habitat area available and landscape connectivity. This scenario is particularly important for assessing the quality of the landscape considering the species most sensitive to biotic and abiotic changes that occur at the edges of the fragments and in the surrounding matrix. It suggests that many of these species, due to difficulties in displacement between habitat remnants, may not have remained in the studied landscape. Proper management of the edges of forest remnants in the landscape, aiming to reduce edge effect and difficulties in displacement between remnants, can be particularly beneficial for the maintenance of populations of the most sensitive species. Planting of forestry species without invasion potential on the edges of fragments to function as a buffer zone and control of lianas on the edges of the remnants are examples of management measures to be studied.

Restoration of the riparian APPs according to the current legislation would increase the native vegetation cover of the studied watershed by only $3.2 \%$. However, this increase would cause a notable positive impact on the landscape quality, as indicated by the metrics used, reducing the fragmentation of the remaining natural vegetation and the number of fragments by connecting them, increasing the average area, and reducing the average distance between the fragments - changes favorable to the increase of structural connectivity. The most evident positive impact of restoration of the riparian APPs would be the increase in connectivity, represented by the PROX values, which would promote a more favorable condition in terms of the possibility of gene flow between the remnants and maintenance of viable populations.

Due to its positive impacts on landscape ecology, restoration of the riparian APPs in the region of the study area can significantly favor the implementation of the Parana River Biodiversity Corridor. This type of action is quite simpler to implement compared to the establishment of large local corridors. Thus, it is suggested that this type of initiative be considered among the priority actions envisioned for the implementation of the Parana River Biodiversity Corridor.

\section{ACKNOWLEDGEMENTS}

The authors are grateful to Fundação Araucária for the Master's Degree scholarship granted to the first author.

\section{SUBMISSION STATUS}

Received: 25 feb., 2016

Accepted: 30 jun., 2018 


\section{CORRESPONDENCE TO}

\section{Roque Cielo-Filho}

Floresta Estadual de Avaré, Instituto Florestal - IF, Rua Pernambuco, s/n, CEP 18701-180, Avaré, SP, Brasil

e-mail: cielofbr@gmail.com

\section{FINANCIAL SUPPORT}

Fundação Araucária, grant no. 862/2013.

\section{REFERENCES}

Aguiar WM, Gaglianone MC. Euglossine bee communities in small forest fragments of the Atlantic Forest, Rio de Janeiro state, southeastern Brazil (Hymenoptera, Apidae). Revista Brasileira de Entomologia 2012; 56(2): 210-219. http://dx.doi.org/10.1590/S0085-56262012005000018.

Awade M, Metzger JP. Using gap - crossing capacity to evaluate functional connectivity of two Atlantic rainforest birds and their response to fragmentation. Austral Ecology 2008; 33(7): 863-871. http://dx.doi.org/10.1111/j.14429993.2008.01857.x.

Brasil. Instituto Nacional de Colonização e Reforma Agrária - INCRA. Instrução Especial/INCRA/n ${ }^{\circ} 20$, de 28 de maio de 1980. Estabelece o Módulo Fiscal de cada Município, previsto no Decreto $n^{\circ} 84.685$, de 06 de maio de 1980. Diário Oficial da República Federativa do Brasil. Brasília, DF (1980 jun. 12); Sec. 1: 11.606.

Brasil. Lei no 12.651, de 25 de maio de 2012. Dispõe sobre a proteção da vegetação nativa; altera as Leis $n^{o s} 6.938$, de 31 de agosto de 1981, 9.393, de 19 de dezembro de 1996, e 11.428, de 22 de dezembro de 2006; revoga as Leis $n^{\text {os }}$ 4.771, de 15 de setembro de 1965, e 7.754, de 14 de abril de 1989, e a Medida Provisória n ${ }^{\circ}$ 2.166-67, de 24 de agosto de 2001; e dá outras providências. Diário Oficial da República Federativa do Brasil. Brasília, DF (2012 maio 25); Sec. 1.

Calegari L, Martins SV, Gleriani JM, Silva E, Busato LC. Análise da dinâmica de fragmentos florestais no município de Carandaí, MG, para fins de restauração florestal. Revista Árvore 2010; 34(5): 871-880. http://dx.doi.org/10.1590/ S0100-67622010000500012.

Christofoletti A. Geomorfologia. São Paulo: Edgar Blucher/ USP; 1974.

Di Bitetti MS, Placci G, Dietz LS. Uma visão de Biodiversidade para a Ecorregião Florestas do Alto Paraná - Bioma Mata Atlântica: planejando a paisagem de conservação da biodiversidade e estabelecendo prioridades para ações de conservação [online]. 2003 [cited 2015 Mar 1]. Available from: http://www.mma.gov.br/estruturas/pda/_arquivos/ prj_mc_061_pub_liv_001_rf.pdf
Fontoura SB, Ganade G, Larocca J. Changes in plant community diversity and composition across an edge between Araucaria forest and pasture in South Brazil. Revista Brasileira de Botanica. Brazilian Journal of Botany 2006; 29(1): 79-91. http://dx.doi.org/10.1590/S010084042006000100008 .

Gomide LR, Lingnau C. Simulação espacial de uma paisagem sob o efeito borda. Revista Floresta 2009; 39(2): 441-455. http://dx.doi.org/10.5380/rf.v39i2.14571.

Greggio TC, Pissarra TCT, Rodrigues FM. Avaliação dos fragmentos florestais do município de JaboticabalSP. Revista Árvore 2009; 33(1): 117-124. http://dx.doi. org/10.1590/S0100-67622009000100012.

Harper KA, MacDonald SE, Burton PJ, Chen J, Brosofske $\mathrm{KD}$, Saunders SC, et al. Edge influence on forest structure and composition in fragmented landscapes. Conservation Biology 2005; 19(3): 768-782. http://dx.doi.org/10.1111/ j.1523-1739.2005.00045.x.

Itaipu Binacional. Reposição Florestal [online]. 2015a [cited 2015 Mar 1]. Available from: http://www.itaipu. gov.br/meioambiente/reposicaoflorestal

Itaipu Binacional. Corredor de Biodiversidade Santa Maria [online]. 2015b [cited 2015 Mar 1]. Available from: http://www.itaipu.gov.br/meioambiente/corredorde-biodiversidade

Jesus FM, Pivello VR, Meirelles ST, Franco GADC, Metzger JP. The importance of landscape structure for seed dispersal in rain forest fragments. Journal of Vegetation Science 2012; 23(6): 1126-1136. http://dx.doi. org/10.1111/j.1654-1103.2012.01418.x.

Lees AC, Peres CA. Conservation value of remnant riparian forest corridors of varying quality for Amazonian birds and mammals. Conservation Biology 2008; 22(2): 439449. http://dx.doi.org/10.1111/j.1523-1739.2007.00870.x. PMid:18241239.

Lima WP, Zákia MJB. Hidrologia de matas ciliares. In: Rodrigues RR, Leitão HF Fo, editores. Matas ciliares: conservação e recuperação. São Paulo: EDUSP/FAPESP; 2000

McGarigal K, Marks BJ. FRAGSTATS: spatial pattern analysis program for quantifying landscape structure [online]. 1995[cited 2015 Mar 1]. Available from: https:// andrewsforest.oregonstate.edu/publications/1538

Mello K, Petri L, Leite EC, Toppa RH. Cenários ambientais para o ordenamento territorial de áreas de preservação permanente no município de Sorocaba, SP. Revista Árvore 2014; 38(2): 309-317. http://dx.doi.org/10.1590/S010067622014000200011 .

Metzger JP. Conservation issues in the Brazilian Atlantic forest. Biological Conservation 2009; 142(6): 1138-1140. http://dx.doi.org/10.1016/j.biocon.2008.10.012.

Milet-Pinheiro P, Schlindwein C. Do euglossine males (Apidae, Euglossini) leave tropical rainforest to collect fragrances in sugarcane monocultures? Revista Brasileira de 
Zoologia 2005; 22(4): 853-858. http://dx.doi.org/10.1590/ S0101-81752005000400008.

Muchailh MC, Roderjan CV, Campos JB, Machado ALT, Curcio GR. Metodologia de planejamento de paisagens fragmentadas visando a formação de corredores ecológicos. Revista Floresta 2010; 40(1): 147-162. http://dx.doi. org/10.5380/rf.v40i1.17106.

Paraná. Secretaria da Agricultura e do Abastecimento - SEAB. Departamento de Economia Rural - DERAL. Perfil da agropecuária do Paraná. Curitiba: SEAB; 2003.

Ribeiro MC, Metzger JP, Martensen AC, Ponzoni FJ, Hirota MM. The Brazilian Atlantic Forest: how much is left, and how is the remaining forest distributed? Implications for conservation. Biological Conservation 2009; 142(6): 1141-1153. https://doi.org/10.1016/j.biocon.2009.02.021.
Silvério RS No, Bento MC, Menezes SJMC, Almeida FS. Caracterização da cobertura florestal de unidades de conservação da Mata Atlântica. Floresta e Ambiente 2015; 22(1): 32-41. http://dx.doi.org/10.1590/2179-8087.058013.

Tabarelli M, Lopes AV, Peres CA. Edge-effects drive tropical forest fragments towards an early-successional system. Biotropica 2008; 46(6): 657-661. http://dx.doi. org/10.1111/j.1744-7429.2008.00454.x.

Tossulino MGP, Schaitza EG, Siqueira JDP, Sayama C, Morato SAA, Ulandowski LK et al. Resumo executivo da avaliação ecológica rápida do Corredor Iguaçu-Paraná. Curitiba: IAP; 2007.

Vidolin GP, Biondi D, Wandembruck A. Análise da estrutura da paisagem de um remanescente de floresta com Araucária, Paraná, Brasil. Revista Árvore 2011; 35(3): 515525. http://dx.doi.org/10.1590/S0100-67622011000300014. 